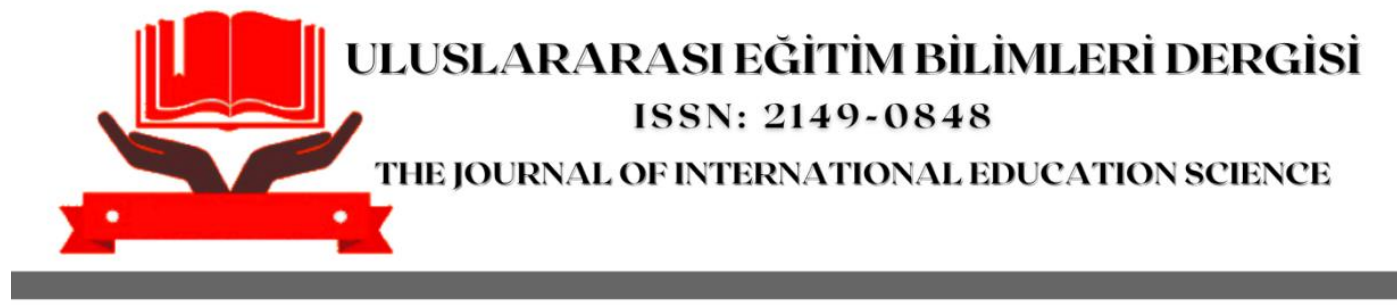

A STUDY ON DEVELOPING A

KIRGIZ ÖĞRETMEN ADAYLARI

ÜZERINNDE BİR ÖZ YETERLİK ÖLÇEĞİ

GELIŞTIRILMESİ

Yener ÖZEN*

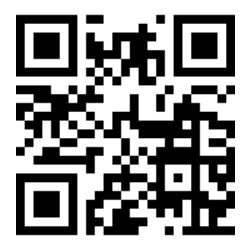

$\begin{array}{ll}\text { Submitted / Geliş: } & 31.03 .2021 \\ \text { Accepted / Kabul: } & 24.06 .2021 \\ \text { Published /Yayın: } & 30.06 .2021 \\ \text { dol 10.29228/INESJOURNAL.50635 }\end{array}$

Article Information: Research Article Makale Türü:

Araştırma Makalesi

Citation / Atıf

Özen, Y. (2021). A study on developing a self-efficacy scale: sample of Kyrgyz prospective teachers. The Journal of International Education Science, 27 (8), 12-26.

Özen, Y. (2021). Kırgız öğretmen adayları üzerinde bir öz yeterlik ölçeği geliştirilmesi. The Journal of International Education Science, 27 (8), 12-26.

This article was checked by Intihal.net. Bu makale İntihal.net tarafından taranmıştır.

This article is under the Creative Commons license. Bu makale Creative Commons lisansı altındadır.

* Assoc. Prof. Dr., Erzincan Binali Yıldırım University, yenerozen@gmail.com 


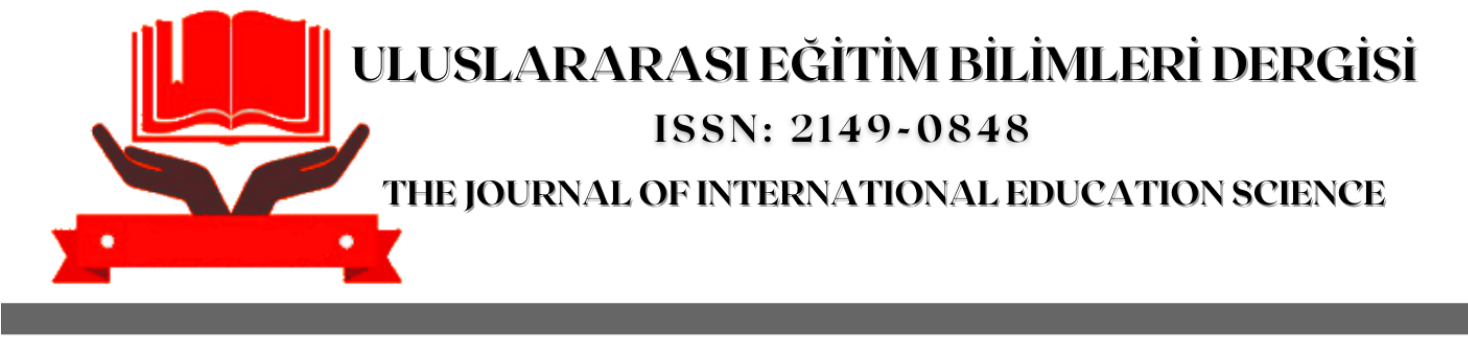

\title{
A STUDY ON DEVELOPING A SELF-EFFICACY SCALE: SAMPLE OF KYRGYZ PROSPECTIVE TEACHERS*
}

\section{KIRGIZ ÖĞRETMEN ADAYLARI ÜZERINDE BİR ÖZ YETERLİK ÖLÇEĞİ GELIŞTIRILMESI}

\section{Assoc. Prof. Dr. Yener ÖZEN}

\begin{abstract}
Self-efficacy is defined as someone's belief in her/himself on being capable of doing or engaging tasks. Thus, self-efficacy plays an important role in futureoriented perspectives/aims. Since social sciences include human behaviors, researchers heavily use questionnaires to collect data and understand human psychological attributes which might be understood clearly through items representing the domain of interest. So, using and creating effective measures for educational purposes becomes essential. Students, who have high self-efficacy, may take responsibilities of their own learning, can regulate their long and short term aims, and develop learning strategies. However, teachers play an important role for students in developing those skills since students do not have much experience in structuring their efforts in proper ways. Most effective teachers are the ones who model positive perspectives of self-learning regulations for each student they interact with. This may be done through class discussions, giving the feeling of self-respect and self-worth. Activities to increase self-efficacy are not only limited to those listed. For example, a cooperative writing activity not only enhances learning but also increases self-efficacy of the students. Self-efficacy measures might be used for teachers and students for different purposes. However present self-efficacy scales rely on their respective cultural values. Therefore, the purpose of this study is to develop a new self-efficacy scale (SES). Self-Efficacy Scale (SES) is prepared with 27 items. Prepared SES consists of items with Likert type. Sample of the study consist of 154 college students who study at teaching department. Principal axis factoring with orthogonal rotation (varimax) is used for exploratory factor analysis. Initial analysis revealed three factors. However, reliability of two factors turned out to be
\end{abstract}

\footnotetext{
* Statements of "COPE-Code of Conduct and Best Practices Guidelines for Journal Editors": No conflicts of interest were reported for this article. Ethics committee approval is required for this study.

“COPE-Dergi Editörleri İçin Davranış Kuralları ve En İyi Uygulama İlkeleri” beyanları: Bu çalışma için herhangi bir çıkar çatışması bildirilmemiştir. Bu çalışma için etik kurul onayı gerekmemektedir.
} 
low so they are omitted. Factor analysis with same procedure is reconducted and emerged with one factor leaving SES with 14 items along with Cronbach's alpha $=.930$ Finalized SES consists of 20 items with six (6) filler and nine (9) reverse coded items. It is decided that created SES might be used for future studies to be used in cultures which have similar values.

Key Words: Self-efficacy, scale construction, students, department of teaching.

Öz: Öz-yeterlik, bir kişinin görevleri yerine getirebileceğine veya meşgul olabileceğine dair kendisine olan inancı olarak tanımlanır. Bu nedenle öz-yeterlik, geleceğe yönelik bakış açıları/amaçlarında önemli bir rol oynamaktadır. Sosyal bilimler insan davranışlarını içerdiğinden, araştırmacılar veri toplamak ve ilgi alanını temsil eden öğeler aracılı̆̆ıyla açıkça anlaşılabilecek insan psikolojik özelliklerini anlamak için anketleri yoğun olarak kullanırlar. Bu nedenle, eğitim amaçlı etkili önlemler kullanmak ve oluşturmak elzem hale geliyor. Öz yeterliliği yüksek olan öğrenciler kendi öğrenmelerinin sorumluluğunu alabilir, uzun ve kısa vadeli amaçlarını düzenleyebilir, öğrenme stratejileri geliştirebilirler. Ancak, öğrencilerin çabalarını uygun şekillerde yapılandırma konusunda fazla deneyimleri olmadığından, öğretmenler bu becerileri geliştirmede öğrenciler için önemli bir rol oynamaktadır. En etkili öğretmenler, etkileşimde bulundukları her öğrenci için kendi kendine öğrenme düzenlemelerinin olumlu bakış açılarını modelleyenlerdir. Bu, öz saygı ve öz değer duygusu vererek sınıf tartışmaları yoluyla yapılabilir. Öz yeterliliği artırmaya yönelik faaliyetler sadece sıralananlarla sınırlı değildir. Örneğin, işbirlikli bir yazma etkinliği sadece öğrenmeyi geliştirmekle kalmaz, aynı zamanda öğrencilerin öz yeterliliğini de arttırır. Öz-yeterlik ölçütleri öğretmenler ve öğrenciler için farklı amaçlarla kullanılabilir. Ancak mevcut öz-yeterlik ölçekleri kendi kültürel değerlerine dayanmaktadır. Bu nedenle bu çalışmanın amacı yeni bir öz-yeterlik ölçeği (SES) oluşturmaktır. Öz Yeterlik Ölçeği (SES) 27 madde ile hazırlanmıştır. Hazırlanan SES, likert tipi maddelerden oluşmaktadır. Araştırmanın örneklemini öğretmenlik bölümünde okuyan 154 üniversite öğrencisi oluşturmaktadır. Açımlayıcı faktör analizi için ortogonal döndürmeli (varimax) ana eksen faktoringi kullanılır. İlk analiz üç faktörü ortaya çıkardı. Ancak iki faktörün güvenilirliği düşük olduğu için ihmal edilmiştir. Aynı prosedürle yapılan faktör analizi yeniden yapılmış ve bir faktörle SES'ten 14 madde bırakılarak ortaya çıkmıştır. Cronbach's alpha $=.930$ Sonlandırılmış SES, altı (6) dolgu ve dokuz (9) ters kodlu maddeden oluşan 20 maddeden oluşmaktadır. Oluşturulan SES'in benzer değerlere sahip kültürlerde kullanılmak üzere ileriki çalışmalarda kullanılabileceğine karar verilmiştir.

Anahtar Kelimeler: Öz-yeterlik, ölçek oluşturma, öğrenciler, öğretmenlik bölümü. 


\section{INTRODUCTION}

Self-efficacy is defined as someone's belief in her/himself on being capable of doing or engaging tasks. Thus, self-efficacy plays an important role in future-oriented perspectives/aims (Karwowski \& Kaufman, 2017). Since social sciences include human behaviors, researchers heavily use questionnaires to collect data and understand human psychological attributes which might be understood clearly through items representing the domain of interest (Hinkin, 1998; Wong \& Lian, 2003). So, using and creating effective measures for educational purposes becomes essential (Hinkin, 1998; Hinkin, Tracey \& Enz, 1997).

Students, who have high self-efficacy, may take responsibilities of their own learning, can regulate their long and short term aims, and develop learning strategies. However, teachers play an important role for students in developing those skills since students do not have much experience in structuring their efforts in proper ways. Most effective teachers are the ones who model positive perspectives of self-learning regulations for each student they interact with. This may be done through class discussions, giving the feeling of self-respect and self-worth. Activities to increase self-efficacy are not only limited to those listed. For example, a cooperative writing activity not only enhances learning but also increases self-efficacy of the students (Troia, Harbaugh, Shankland, Wolbers \& Lawrence, 2013; Zimmerman, Bonner and Kovach, 1996).

However, it should be noted that teachers are not only supposed to know and apply instruction methods and techniques but also exhibit positive attitudes and feelings. Teachers should know supportive ways and education faculties should also focus on training teacher candidates (students) and teaching how to have and exhibit supportive ways. (Enochs \& Riggs, 1990). Through that, hopefully, teachers will know how to have their own source of efficacy and then will create a supportive environment for their students. Studies point out those teachers who have high self-efficacy values are eager to try different and new techniques in the classroom and are eager to learn different approaches. On the other hand, teachers with low selfefficacy values tend to avoid using new approaches or techniques and keen to use traditional approaches where they can also avoid taking responsibilities (i.e avoid risks) (Bursal, 2010; Berg \& Smith, 2016;).

Thus, teachers should master their students' time management by helping them to create their own learning strategies. However, lack of improvement of self-efficacy or making students believe that they will have immediate results may have catastrophic effects on selfconfidence. (Zimmerman et al., 1996). Thus, teachers should be aware of the fact that they will not always have solid data on increase of self-efficacy since the progress itself may take a while to reveal itself. Even motivation itself may have a direct effect on achievement and have impact on self-belief (Lovelace \& Brickman, 2013) where quantitative measures are used as a representation of an abstract construct (Hinkin, 1998). But self-efficacy beliefs may vary across cultures which include both personal and interpersonal experiences such as beliefs, faiths, socioeconomic status and school achievement. Then it is obvious to indicate that each self-efficacy scale reflects its applied culture (Berg \& Smith, 2016; Bandura, 2006). Consequently, self-efficacy scales must have derived upon its applied culture (Karwowski \& Kaufman, 2017) since it will give information on one's psychological position on a specific subject (Brinkman, 2009). For that 
reason, the purpose of the study is to create a self-efficacy scale proper to its applied culture.

\section{METHOD}

1.1. Creating new self-efficacy scale: To achieve purpose of the study, literature research has been done for different self-efficacy scales and obtained scales were analyzed. To create a new scale some guidelines are determined. Created guideline is based on suggestions acquired from literature (Brinkman, 2009; Johanson \& Brooks, 2010; Hinkin, 1998; Hinkin et.al., 1997; Kato, 2013; Schwarzer \& Jerusalem, 1995; Schwarzer \& Jerusalem, 1996; Muris, 2001; 2002; Bandura, 2006; Wong \& Lian 2003; Enochs \& Riggs, 1990). Those guidelines are;

a) Language should be clear and appropriate to respondents.

b) No to cause any bias, content must be familiar with students' culture (schemes)

c) Respondents should not feel that they rate their feelings but place themselves at a position. Thus, scale is created a 5 level likert type. However, instead of marking ratings they choose the place they feel right. For that reason, letter points from A to E is used for rating.

d) Items must include a single topic and asses a single behavior or response.

e) Items used must not sound abstract or vague so that questions could not be interpreted in different ways.

f) Leading questions should be avoided.

g) Language and expected knowledge should be familiar for the target group.

h) Sensitive questions or sentences, double negative questions should be avoided.

i) Intervals between the questions should not remind the respondents their previous answers (i.e control questions should not awake the feeling for the respondents that their answers are being/will be checked)

Thus, maximum information would have been gathered with minimum cost. Although a qualitative study might reveal more in-depth idea regarding the students' ideas and attitudes. A quantitative study might reveal a direct result and might be completed in much shorter time since it ensures easy compilation and generalize the scale to population. Obtained scales are analyzed for their harmony with Kyrgyz culture and a new scale is created based on guideline. For the best practice for analysis and interpretation of data some measures are taken account such as different scale preparation advisements, regarding but not limited to assessing values, beliefs, cultural values of students, possible different instructor effects, instructional methods used for education, number of questions asked, appropriateness to common usage, item degree, respond type and lengthy design. (Lovelace \& Brickman, 2013; Brinkman, 2009; Johanson \& Brooks, 2010). So, among Thurstone's method of equal-appearing intervals, Likert scale, Semantic differential scales it is determined that a Likert type scale would be more beneficial for the purpose of the study.

Candidate pool of items are selected for the scale and then maximum number of items is determined so that respondents will not get bored and will respond the scale within attention time to ensure content adequacy. Item degree is determined to ensure that respondents will not make grading like from 1 to 10 but instead place themselves in a position. For that purpose, sentences "I completely agree" or "I completely disagree" are given at the beginning of the scale 
as information but scale itself marked those sentences from A to E. A is the strongest confirmation signal while $\mathrm{E}$ is the least confirmation signal. By placing 5 level of response for an item it is ensured that internal consistency reliability is increased, and sufficient variances are obtained since a four (4) point value would be beneficial for the purpose. Hinkin (1998) points out that most respondents tend to choose options at the edges thus reversed coded sentences are appropriately used to trigger vigilance of respondents (Hinkin, 1998; Lovelace \& Brickman, 2013; Brinkman, 2009; Hinkin et al., 1997). Thus, created scale is a Likert type scale since it is regarded as most useful in behavioral research and suitable for factor analysis (Hinkin, 1998; Hinkin et al., 1997).

1.2. Created self-efficacy scale: Created scale applied to a small group of teacher candidates for pilot study. Response rate of the created scale (items) and their response to scale is determined (i.e questions whose meanings asked by the respondents are immediately omitted from the scale since it is determined that those sentences are vague or abstract to respondents). After that prepared scale was analyzed by instructors and educators who have the experience of teaching and have research on related issues since specialists could value the prepared scale on content domain (Hinkin et al., 1997). After determining the items, their number and its content, scale is finalized. Created Self Efficacy Scale (SES) consists of 27 questions (Q). A possible value of high number of the items included in the scale to ensure scale catches its purpose. Benefit of increasing the questions is that the reliability increases with the number of questions. However, it should be noted that it has been also tried to ensure that respondents will not have the feeling of replying same/similar questions directed to them in different sentences. By doing so, it is ensured that respondents will not get bored, and they reply the questions willingly (Brinkman, 2009). SES consists of 8 filler questions and 10 are reverse coded questions. Filler questions are Q1, Q6, Q7, Q13, Q20, Q22, Q25 and Q26. Reverse coded questions are Q3, Q5, Q8, Q9, Q11, Q12, Q17, Q19, Q21 and Q27.

1.3. Determining the sample size and sampling: Finalized scale is applied to college students who are studying at teaching departments which is suitable for the purpose (Hinkin, 1998). Reason for selecting teaching departments is that nature of the sample has the largest impact on accuracy of parameter estimates in order to avoid measurement errors. It is important to choose adequate sampling, by doing this unrepresentative sample will not be used in the study. Through that, it is decided that sample represents the population of interest for larger study (Johanson \& Brooks, 2010; Hinkin, 1998). In order to ensure the anonymity, (i.e. avoiding conflict of interest) no information is required from the students. After applying the scale, control questions were run, and students' scales whose responses did not fit in the control questions' range are omitted from the study thus leaving 154 data of students. Purpose of running control questions is to reduce/eliminate the chance factor of someone who gives wrong answer about his/her idea on the subject/topic. For that reason, sample of the study consists of 154 students.

Choosing a sample size is controversial debate. Some researchers argue about arbitrary sampling which presents high communalities without cross loadings. So sampling may be determined by nature of data i.e stronger the data smaller the sampling, while others argue on item-ratio. Debate on item-ratio suggests proportion from 1:2 to 1:10 for item and sampling 
(Anthoine, Moret, Regnault, Sébille \& Hardouin, 2014; Hinkin, 1998; Hinkin, Tracey \& Enz, 1997). For example, Johanson \& Brooks (2010) point out that literature on social research suggest $\mathrm{N}$ between 10 and 30 for creating scales and pilot studies might be useful with benefits such as simplicity, easy calculation and the ability to test hypotheses. In addition, researchers also point out $\mathrm{N}=100$ for sampling also suggested in literature. For a comprehensive item analysis N=100 to 200 also should be conducted since (suggested) standard errors for Cronbach's alpha increases as the sample size decreases. However, it is also noted that regardless the number of items (might be even two items), mean inter-item correlation is nominal between $\mathrm{N}=30$ to 200. Yet, researchers conclude in their study that $\mathrm{N}=30$ would be reasonable enough for pilot studies when the purpose is preliminary survey or scale development. Additionally, Hinkin (1998) and Hinkin et al., (1997) suggest N=150 to obtain sufficient data for exploratory factor analysis if item inter-correlations are reasonably strong and for confirmatory factor analysis $\mathrm{N}=100$ is recommended. However, researchers also mention difference between statistical and practical significance must be noted since attaining statistical difference increases as the sample size increases. Larger samples are in fact useful to detect small fluctuations. However, as sample size increases practical meaning of the results may distort so decision on sample size must be taken with caution. Having 1:8 item-ratio and number of participants (154), it is decided that sample of the study is adequate for the research.

\section{FINDINGS}

2.1. Exploratory factor analysis: a principal axis is conducted on the 19 items with orthogonal rotation (varimax) through SPSS program to reveal the factors within the created scale. The Kaiser-Meyer-Olkin measure verified the sampling adequacy for the analysis as $\mathrm{KMO}=.89$ ("meritorious" according to Hinkin, 1998) which is above the acceptable limit of .5 and Bartlett's test of sphericity $\left(\mathrm{x}^{2}(171)=1474.381, \mathrm{p}=.00<.05\right)$ is to be found significant. An initial analysis is run to obtain eigenvalues for each factor in the data. Three factors emerged having eigenvalues over Kaiser's criterion of 1 and in combination explained \%56,857 of the variance. The scree plot (Figure 1) is obtained, and it is decided that scale has three factors with respect to convergence of scree plot and Kaiser's criterion on this value.

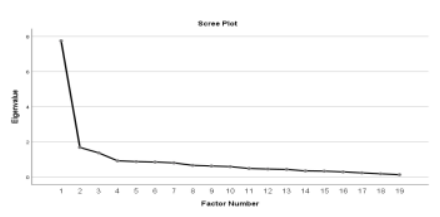

Figure 1 Scree plot 
Eigenvalue of the factors are 7,$7749 ; 1,681 ; 1,372$ respectively for factor 1,2 and 3 . In addition, variances shared by the factors are 40,$786 ; 8,850$ and 7,222 . The three factors share $\%$ 56,857 of the total variance. Table 1 shows the factor loadings after rotation.

Table 1 Factor loadings

\begin{tabular}{llll}
\hline & Factor 1 & Factor 2 & Factor 3 \\
\hline Q15 &, 890 & & \\
\hline Q21 &, 816 & & \\
\hline Q4 &, 774 & & \\
\hline Q24 &, 751 & & \\
\hline Q12 &, 710 & & \\
\hline Q9 &, 704 & & \\
\hline Q5 &, 681 &, 331 & \\
\hline Q14 &, 617 &, 305 & \\
\hline Q11 &, 613 &, 301 & \\
\hline Q17 &, 611 & & \\
\hline Q2 &, 586 & &, 3618 \\
\hline Q19 &, 538 &, 657 &, 341 \\
\hline Q27 &, 535 &, 573 & \\
\hline Q8 &, 476 & & \\
\hline Q10 & & \\
\hline Q23 & & & \\
\hline Q3 & & \\
\hline Q16 & & \\
\hline Q18 & & & \\
\hline
\end{tabular}

* Factors loadings are ordered in order of magnitude.

It is clear from Table 1 that Q10 and Q23 are under factor 2 where Q3, Q16 and Q18 are under factor 3 while rest of the questions are under factor 1 . For further analysis reliability of each factor is calculated as suggested (Field, 2013) and shown in Table 2.

Table 2 Reliability

\begin{tabular}{lcc}
\hline & Cronbach's Alpha & Number of items \\
\hline Factor 1 &, 930 & 14 \\
\hline Factor 2 &, 505 & 2 \\
\hline Factor 3 &, 377 & 3 \\
\hline
\end{tabular}

Since the reliability of factor 2 is low and factor 3 not reliable, and there is no chance of increase in reliability after removing items, factor 2 and factor 3 are omitted from the scale along with their items. Thus, leaving factor 1 and its items. A principal axis is reconducted on the 14 items with orthogonal rotation (varimax) through SPSS program to reveal the factors within the created scale. The Kaiser-Meyer-Olkin measure verified the sampling adequacy for the analysis, $\mathrm{KMO}=.913$ ("marvelous" according to Hinkin, 1998) which is above the acceptable limit of .5 and Bartlett's test of sphericity is to be found significant $\left.x^{2}(91)=1266.423, p=.00<.05\right)$. An initial 
analysis is run to obtain eigenvalues for possible factors in the data. One factor emerged as having eigenvalue over Kaiser's criterion of 1 and explained \%49,297 of the variance. The scree plot (Figure 2) is obtained, and it is decided that scale has one factor with respect to convergence of scree plot and Kaiser's criterion on this value. Factor loadings of the items and shared variances are shown in Table 2

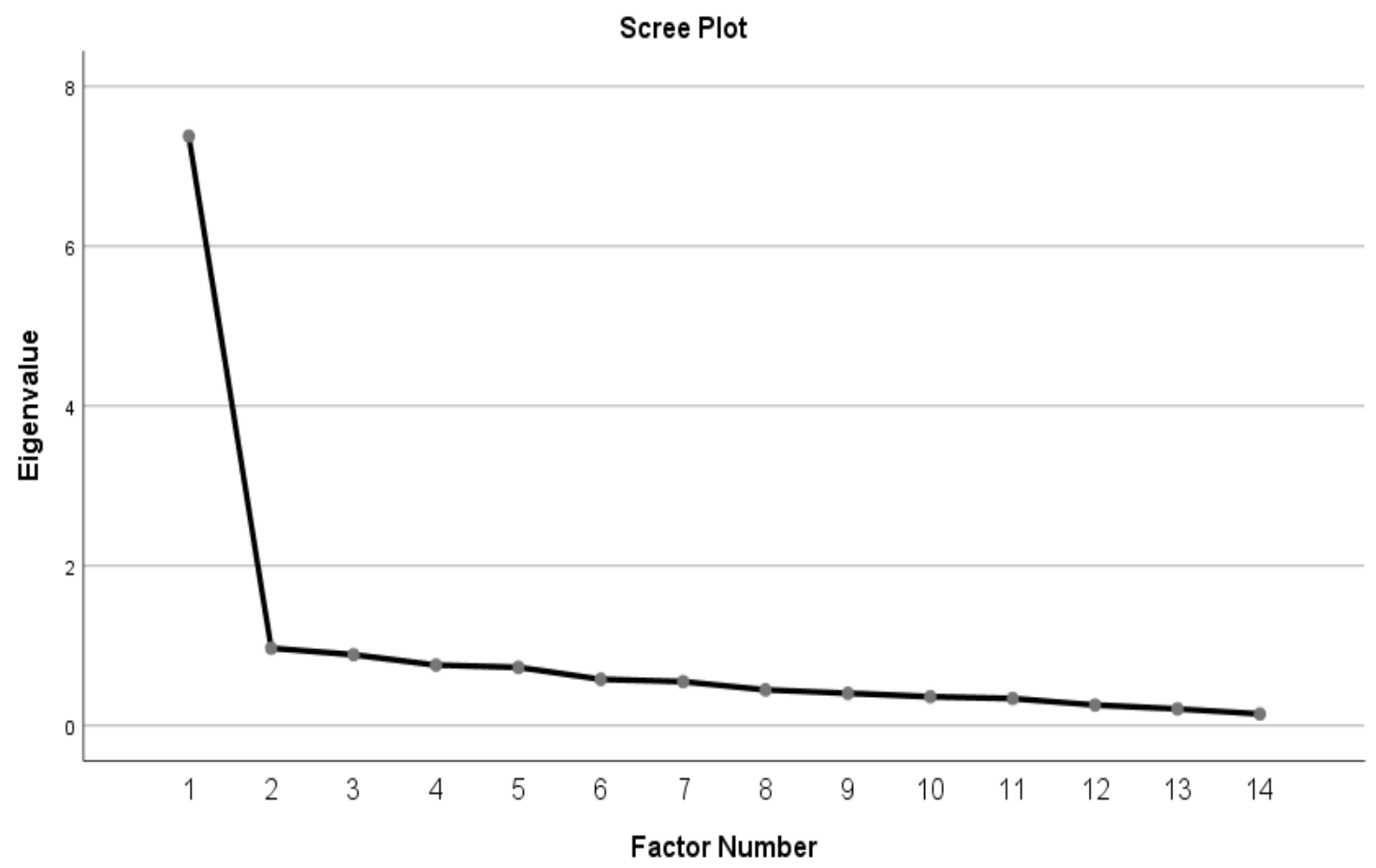

Figure 2 Scree plot

Table 2 Factor loadings

\begin{tabular}{lll}
\hline & Factor & $\mathrm{h}^{2}$ \\
\hline Q15 &, 854 &, 730 \\
\hline Q21 &, 839 &, 705 \\
\hline Q4 &, 785 &, 616 \\
\hline Q24 &, 778 &, 605 \\
\hline Q12 &, 747 &, 559 \\
\hline Q9 &, 688 &, 473 \\
\hline Q5 &, 680 &, 462 \\
\hline Q14 &, 677 &, 459 \\
\hline Q17 &, 668 &, 447 \\
\hline Q2 &, 660 &, 436 \\
\hline Q11 &, 653 &, 426 \\
\hline Q27 &, 608 &, 370 \\
\hline Q8 &, 556 &, 310 \\
\hline Q19 &, 554 &, 306 \\
\hline
\end{tabular}

* Factors loadings are ordered in order of magnitude. 
For further analysis reliability of the factor is calculated as suggested (Field, 2013) and SES' Cronbach's $\alpha=.930$ found as "highly reliable" (Hinkin, 1998). For detailed analysis an independent $t$ samples test is run for each item. Reliability analysis item-total correlation and tupdown(\%27) results are shown in Table 3.

Table 3 Item-total correlation and tup-down(\%27) results

\begin{tabular}{llll}
\hline $\begin{array}{l}\text { Item } \\
\text { code }\end{array}$ & New item code & Corrected-item total correlation & tup-down(\%27) \\
\hline Q2 & SES2 &, 637 & $12,497^{*}$ \\
\hline Q4 & SES3 &, 749 & $16,370^{*}$ \\
\hline Q5 & SES4 &, 659 & $14,792^{*}$ \\
\hline Q8 & SES7 &, 537 & $8,310^{*}$ \\
\hline Q9 & SES8 &, 659 & $11,028^{*}$ \\
\hline Q11 & SES9 &, 634 & $11,765^{*}$ \\
\hline Q12 & SES10 &, 720 & $13,980^{*}$ \\
\hline Q14 & SES12 &, 648 & $10,446^{*}$ \\
\hline Q15 & SES13 &, 816 & $22,196^{*}$ \\
\hline Q17 & SES14 &, 646 & $13,603^{*}$ \\
\hline Q19 & SES15 &, 537 & $10,996^{*}$ \\
\hline Q21 & SES17 &, 806 & $21,291^{*}$ \\
\hline Q24 & SES19 &, 751 & $17,418^{*}$ \\
\hline Q27 & SES20 &, 585 & $9,188^{*}$ \\
\hline
\end{tabular}

$* \mathrm{p}<.05$

Since SES validates that it might be used, filler questions are replaced between questions with respect to pilot scale order. SES consists of six (6) filler and nine (9) reverse coded items thus finalized scale consists of 20 questions (Appendix A). Filler questions are SES1, SES5, SES6, SES11, SES16 and SES18. Reversed coded items are SES4, SES7, SES8, SES9, SES10, SES14, SES15, SES17 and SES20. For international readers an English translation of SES also is given in the Appendix B.

\section{DISCUSSION}

Created SES has one factor structure and assesses a general self-efficacy attitude. However, a detailed look upon the $t$ values of $\% 27$ up-down will reveal more insight. Lowest $t$ value obtained from SES7 $(t=8,310)$ which is "I hardly accomplish my my goals when I set them" and SES20 $(9,188)$ "I trouble to overcome obstacles that I encounter in life". Low t values of SES7 and SES20 imply that individuals who can set goals and accomplish them may overcome obstacles they encounter. In another aspect it may be also said that individuals who are having troubles in overcoming obstacles also are having difficulties in achieving set aims. In fact, SES7 targets "action planning" where SES20 targets "coping planning" and studies demonstrates that although action planning is effective in long term behavioral change, "coping planning" is a hidden and strong factor which is affected by experience and hence effective on action planning (Snieehotta, Schwarzer, Scholz \& Schuz, 2005). Effect of experience on cognitive skill develop- 
ment is already accepted by many researchers thus cooperation among the students are encouraged at every opportunities (Hesse, Care, Buder, Sassenberg \& Griffin, 2015). For example, cooperative learning model encourages learning groups and creates heterogeneous groups in which students encounter difficulties, different ideas and obstacles. However through experience it is aimed that every single student will learn how to overcome obstacles and establish long term planning. It should be also noted that instructors play a key role in dramatic increase of experience and problem-solving skills (Crouch \& Mazur, 2001; Hakkinen, Jarvela, MakitaloSiegl, Ahonen, Naykki \& Valtonen, 2017).

The highest $t$ values obtained from SES13 $(t=22,196)$ and SES17 $(21,291)$ already confirms that argument. SES17 shows that students with lower low self-efficacy values "give up trying/learning" if they fail to accomplish the task. In other words, students with high selfefficacy values do not easily give up and focus on the task. This case is approved in t value of SES13 which is "If I decide to do something, I focus on it" and show that students with high self-efficacy values also do not easily give up. Both SES13 and SES17 confirm each other and validate each other. Self-efficacy is one's believed in his/her capability of doing something and it is shaped by past experience. Thus, learning/knowing what to do and how to do is an essential component in self-efficacy (Nguyen, Johnson, Collins \& Parker, 2017). In fact, several researches already indicate that self-efficacy values are related with past experiences (Nissen \& Shemwell, 2016; Robnet, Chemers \& Zurbriggen, 2015).

\section{CONCLUSION}

Clark \& Watson (1995) report that a good scale through factor analysis should reflect unidimensionality. Created SES having both one factor structure and high internal consistency $(\alpha=.930)$ proves itself a powerful scale for the purpose. As a result of analyzes, it is concluded that created self-efficacy scale will be helpful to researchers and educators who want to use it in educational and social purposes. For further analysis SES might be used in different region of Kyrgyzstan and neighborhood regions/states which have similar cultural content. Thus, SES with different samples is also welcomed to compare results and to validate its purpose. For that purpose, created SES is given in the Appendix A.

In addition, SES might be used in different states since an English translation is provided. However, reliability and factor structure of the scale should be restudied. Thus, SES with different international samples is also welcomed to compare results and to validate its purpose. For that purpose, created SES is given in the Appendix B. Finally, researchers, who would like to use the scale, may also use number markings instead of letter markings.

\section{REFERENCES}

Anthoine, E., Moret, L., Regnault, A., Sébille, V., \& Hardouin, J.-B. (2014). Sample size used to validate a scale: a review of publications on newly-developed patient reported outcomes measures. Health and Quality of Life Outcomes, 12 (2), 1-10. DOI: http://doi.org/10.1186/s12955-014-0176-2

Bandura, A. (2006). Self-efficacy beliefs of adolescents. In Pajares, F. \& Urdan, T. (Eds.), Guide for 
constructing self-efficacy scales (pp. 307-337). Greenwich, CT: IAP.

Berg, D.A.G \& Smith, L.F. (2016). Asia-Pacific Perspectives on Teacher Self-Efficacy. In Garvis, S. \& Pendergast, D. (Eds.), Preservice teacher self-efficacy beliefs: An opportunity to generate "good research" in the asia-pacific region (pp. 1-17). Rotterdam: Sense Publishers

Brinkman, W-P. (2009). Handbook of mobile technology research methods. In Love, S. (Eds.), Design of a questionnaire instrument (pp. 31-57). Netherlands: Nova Publisher

Clark, L.A. \& Watson, D. (1995). Constructing validity: Basic issues in objective scale development. Psychological Assessment, 7 (3), 309-319.

Crouch, C. H., \& Mazur, E. (2001). Peer Instruction: Ten years of experience and results. American Journal of Physics, 69 (9), 970-977. DOI:10.1119/1.1374249

Enochs, L.G. \& Riggs, I. M. (1990). Further development of an elementary science teaching efficacy belief instrument: a preservice elementary scale. Proceedings of $63^{\text {rd }}$ annual meeting of the national association for research in science teaching (pp. 1-30). Atlanta, GA: The Center for Science Education. Retrieved from the ERIC database. (ED319601)

Field, A. (2013). Discovering statistics using ibm spss statistics (4 ${ }^{\text {th }}$ Edition). London: SAGE

Hakkinen, P., Jarvela, S., Makitalo-Siegl, K., Ahonen, A., Naykki, P. \& Valtonen, T. (2017). Preparing teacher-students for twenty-first-century learning practices (PREP21): A framework for enhancing collaborative problem-solving and strategic learning skills. Teachers and Teaching, 23 (1), 25-41, DOI: 10.1080/13540602.2016.1203772

Hesse F., Care E., Buder J., Sassenberg K. \& Griffin P. (2015) Assessment and Teaching of 21st Century Skills: Methods and Approach. In: Griffin, P. \& Care, E. (Eds.), A Framework for Teachable Collaborative Problem Solving Skills (pp. 37-56). Dordrecht: Springer

Hinkin, T. R. (1998). A brief tutorial on the development of measures for use in survey questionnaires. Organizational Research Methods, 2 (1), 104-121 DOI:10.1177/109442819800100106

Hinkin, T. R., Tracey, J. B., \& Enz, C. A. (1997). Scale construction: Developing reliable and valid measurement instruments. Journal of Hospitality \& Tourism Research, 21 (1), 100-120. DOI:10.1177/109634809702100108

Johanson, G.A., \& Brooks, G.P. (2010). Initial scale development: Sample size for pilot studies. Educational and Psychological Measurement, 70 (3), 394-400. DOI: $10.1177 / 0013164409355692$

Karwowski, M. \& Kaufman, J.C. (Eds.) (2017). The Creative Self. San Diego, CA: Academic Press.

Kato, P.M. (2013). How do you measure self-efficacy? The answer may surprise you. Retrieved from https://pamkato.com/2013/03/14/how-do-you-measure-self-efficacy-the-answer-maysurprise-you/

Lovelace, M. \& Brickman, P. (2013). Best practices for measuring students' attitudes toward learning science. CBE-Life Sciences Education, 12 (4), 606-617. DOI: 10.1187/cbe.12-11-0197 
Muris, P. (2001). A brief questionnaire for measuring self-efficacy in youths. Journal of Psychopathology and Behavioral Assessment, 23 (3), 145-149. DOI: https://doi.org/10.1023/A:1010961119608

Muris, P. (2002). Relationships between self-efficacy and symptoms of anxiety disorders and depression in a normal adolescent sample. Personality and Individual Differences, 32, 337348

Nguyen, H., Johnson, A., Collins, C. \& Parker, S.K. (2017). Confidence matters: Self-efficacy moderates the credit that supervisors give to adaptive and proactive role behaviors. British Journal of Management, 28, 315-330. DOI: 10.1111/1467-8551.12149

Nissen, J.M. \& Shemwell, J.T. (2016). Gender, experience and self-efficacy in introductory physics. Physical Review Physics Education Research, 12 (2), 1-16. DOI: 10.1103/PhysRevPhysEducRes.12.020105

Robnett, R.D., Chemers, M.M. \& Zurbriggen, E.L. (2015). Longitudinal associations among undergraduates' research experience, self-efficacy and identity. Journal of Research in Science Teaching, 52 (6), 847-867. DOI: 10.1002/tea.21221

Schwarzer, R., \& Jerusalem, M. (1995). Generalized Self-Efficacy scale. In Weinman, J., Wright, S. \& Johnston, M. Measures in health psychology: A user's portfolio. Causal and control beliefs (pp. 35-37). Windsor, UK: NFER-NELSON.

Snieehotta, F.F., Schwarzer, R., Scholz, U. \& Schuz, B. (2005). Action planning and coping planning for long-term lifestyle change: Theory and assessment. European Journal of Social Psychology, 35, 565-576. Doi: 10.1002/ejsp.258

Troia, G.A., Harbaugh, A.G., Shankland, R.K., Wolbers, K.A. \& Lawrence, A.M. (2013). Relationship between writing motivation, writing activity, and performance: Effects of grade, sex and ability. Reading and Writing, 26 (1), 17-44. https://doi.org/10.1007/s11145$\underline{012-9379-2}$

Wong., M. \& Lian, S. (2003). Development of a self-efficacy scale for assessing secondary school students'science self-efficacy beliefs. Retrieved from http://citeseerx.ist.psu.edu/viewdoc/summary?doi=10.1.1.472.8479

Zimmerman, B.J., Bonner, S. \& Kovach, R. (1996). Developing self-regulated learners: Beyond achievement to self-efficacy. Washington, DC: American psychological association. 
Appendix A: САМОЭФФЕКТИВНОСТЬ

\begin{tabular}{|c|c|c|c|c|c|c|}
\hline & САМОЭФФЕКТИВНОСТЬ & & & & & \\
\hline 1 & Мен өз мөмө/жашылча өстүрүҮ үчүн келет & A & B & $\mathrm{C}$ & $\mathbf{D}$ & $\mathrm{E}$ \\
\hline 2 & $\begin{array}{l}\text { Мен пландаштырып жатканда, аны ишке ашыра алат деп } \\
\text { ишенем }\end{array}$ & A & B & $\mathrm{C}$ & $\mathbf{D}$ & $\mathrm{E}$ \\
\hline 3 & $\begin{array}{l}\text { Мен биринчи жолу жумуш кыла албай турган болсо, мен } \\
\text { кайра-кайра, аны аткарууга аракет кылам }\end{array}$ & $\mathbf{A}$ & B & $\mathrm{C}$ & $\mathbf{D}$ & $\mathrm{E}$ \\
\hline 4 & Бул жаңы досторду күттүм кыйын. & A & B & $\mathrm{C}$ & D & $\mathrm{E}$ \\
\hline 5 & $\begin{array}{l}\text { Генетика/тукум куучулук адам табиятын структураны } \\
\text { таасир }\end{array}$ & $\mathbf{A}$ & $\mathbf{B}$ & $\mathrm{C}$ & $\mathbf{D}$ & $\mathbf{E}$ \\
\hline 6 & Кук мен жакшы көрөм. & A & B & $\mathrm{C}$ & $\mathbf{D}$ & $\mathrm{E}$ \\
\hline 7 & $\begin{array}{l}\text { Мен алдыма максат койдум, чанда гана аларды ишке } \\
\text { ашыра алам. }\end{array}$ & $\mathbf{A}$ & $\mathbf{B}$ & $\mathrm{C}$ & $\mathbf{D}$ & $\mathbf{E}$ \\
\hline 8 & $\begin{array}{l}\text { Алар бир нерсе кылар алдында мен жарым нерселерди } \\
\text { таштап. }\end{array}$ & A & B & C & $\mathbf{D}$ & $\mathrm{E}$ \\
\hline 9 & Кыйынчылыктардан качуу мен. & A & B & $\mathrm{C}$ & $\mathbf{D}$ & $\mathrm{E}$ \\
\hline 10 & 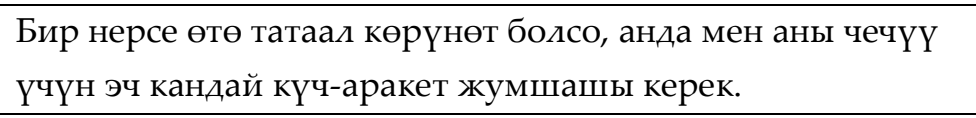 & A & B & $\mathrm{C}$ & $\mathbf{D}$ & $\mathbf{E}$ \\
\hline 11 & Бардык жаратылышта жакшы. & A & B & $\mathrm{C}$ & $\mathbf{D}$ & $\mathbf{E}$ \\
\hline 12 & $\begin{array}{l}\text { Мен жакпайт нерсе менен беттеше турган болсо, мен муну } \\
\text { үчүн бүт күч-аракетибизди жумшайбыз. }\end{array}$ & $\mathbf{A}$ & B & $\mathrm{C}$ & $\mathbf{D}$ & E \\
\hline 13 & Мен бир нерсе кылууну чечсе, мен бул багыт болот. & A & B & $\mathrm{C}$ & $\mathbf{D}$ & $\mathbf{E}$ \\
\hline 14 & Мен алардын жөндөмдүүлүктөрү аз ишеним бар. & A & B & $\mathrm{C}$ & $\mathbf{D}$ & $\mathrm{E}$ \\
\hline 15 & Мен жонокой байланыша албайт. & A & B & $\mathrm{C}$ & $\mathbf{D}$ & E \\
\hline 16 & $\begin{array}{l}\text { Мен сүрөтчү болгон болсо, анда мен балдарды жакындай } \\
\text { келет. }\end{array}$ & $\mathbf{A}$ & B & $\mathrm{C}$ & $\mathbf{D}$ & $\mathrm{E}$ \\
\hline 17 & $\begin{array}{l}\text { Мен биринчи жолу үйрөнүшүбүз мүмкүн эмес болсо, } \\
\text { жаңы бир нерсени үйрөнө баштаганда, мен/ҮйрөнүҮ } \\
\text { токтоткула. }\end{array}$ & A & B & $\mathrm{C}$ & $\mathbf{D}$ & $\mathrm{E}$ \\
\hline 18 & Мен аквариум балыкты тамак жакшы болот. & A & B & $\mathrm{C}$ & $\mathbf{D}$ & $\mathbf{E}$ \\
\hline 19 & Мен өз алдынча жогорку ишеним бар. & A & B & $\mathrm{C}$ & $\mathbf{D}$ & $\mathbf{E}$ \\
\hline 20 & $\begin{array}{l}\text { Мен жашоодо туш болгон көйгөйлөрдү чечүҮ Үчүн } \\
\text { кыйынга турат. }\end{array}$ & A & B & $\mathrm{C}$ & $\mathbf{D}$ & $\mathbf{E}$ \\
\hline
\end{tabular}


Appendix B: Self-Efficacy Scale

\begin{tabular}{|c|l|c|c|c|c|c|}
\hline & SELF EFFICACY & A & B & C & D & E \\
\hline $\mathbf{1}$ & I would like to grow my own vegetables/fruits & A & B & C & D & E \\
\hline $\mathbf{2}$ & I am sure that I am capable of executing my plans & A & B & C & D & E \\
\hline $\mathbf{3}$ & If I can't do something first time, I try over and over & A & B & C & D & E \\
\hline $\mathbf{4}$ & I hardly establish friendship & A & B & C & D & E \\
\hline $\mathbf{5}$ & Genetics/heredity affects the character & A & B & C & D & E \\
\hline $\mathbf{6}$ & I like to cook & A & B & C & D & E \\
\hline $\mathbf{7}$ & I hardly accomplish my goals when I set them & A & B & C & D & E \\
\hline $\mathbf{8}$ & I leave things uncompleted & A & B & C & D & E \\
\hline $\mathbf{9}$ & I avoid to encounter the obstacles & A & B & C & D & E \\
\hline $\mathbf{1 0}$ & I don't spend effort if it seems very complicated & A & B & C & D & E \\
\hline $\mathbf{1 1}$ & Everyone is essentially good & A & B & C & D & E \\
\hline $\mathbf{1 2}$ & $\begin{array}{l}\text { If I encounter an obstacle which I don't like, I try to overcome } \\
\text { it with all my efforts }\end{array}$ & & & & & \\
\hline $\mathbf{1 3}$ & If I decide to do something, I focus on it & B & C & D & E \\
\hline $\mathbf{1 4}$ & I hardly believe in my capability & A & B & C & D & E \\
\hline $\mathbf{1 5}$ & I can't socialize easily & A & B & C & D & E \\
\hline $\mathbf{1 6}$ & $\begin{array}{l}\text { If I was an artist then I would want to paint picture of chil- } \\
\text { dren }\end{array}$ & A & B & C & D & E \\
\hline $\mathbf{1 7}$ & $\begin{array}{l}\text { When I start to learn something new and can't learn at first } \\
\text { then I give up studying/try learning }\end{array}$ & A & B & C & D & E \\
\hline $\mathbf{1 8}$ & I would like to have fish as pet & A & B & C & D & E \\
\hline $\mathbf{1 9}$ & My self confidence is high & A & B & C & D & E \\
\hline $\mathbf{2 0}$ & I trouble to overcome obstacles that I encounter in life & E \\
\hline & & & \\
\hline
\end{tabular}

